\title{
PELATIHAN TECHNOPRENEURSHIP DAN WORKSHOP FUSION 360 DI SMAN 110 JAKARTA DALAM RANGKA MENINGKATKAN DAYA SAING BANGSA
}

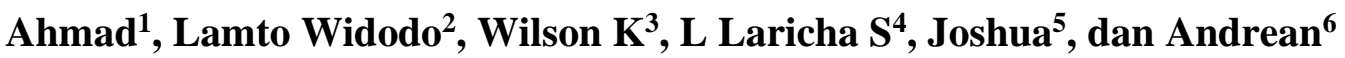 \\ ${ }^{1}$ Program studi Teknik Industri Universitas Tarumanagara \\ Email: Ahmad@ft.untar.ac.id \\ ${ }^{2}$ Program studi Teknik Industri Universitas Tarumanagara \\ Email: lamtow@ft.untar.ac.id \\ ${ }^{3}$ Program studi Teknik Industri Universitas Tarumanagara \\ Email:wilsonk@ft.untar.ac.id \\ ${ }^{4}$ Program studi Teknik Industri Universitas Tarumanagara \\ Email: lithrones@ft.untar.ac.id \\ ${ }^{5}$ Mahasiswa Prodi Teknik Industri Universitas Tarumanagara \\ Email: jhosua.545170065@stu.untar.ac.id \\ ${ }^{6}$ Mahasiswa Prodi Teknik Industri Universitas Tarumanagara \\ Email: andrean.545170065@stu.untar.ac.id
}

\begin{abstract}
The needs of today's consumers are very complex and change rapidly. Of course, this requires higher soft skills in response to realizing product designs that are in accordance with consumer desires. Unique and creative product designs certainly consider various aspects such as aspects of functionality, ergonomic aspects, industrial design aspects, mechanical aspects, manufacturing aspects, including aspects of market studies and analysis. These various aspects are deemed necessary to be introduced in the form of workshops for high school level students, such as at SMAN 110 Jakarta, where many graduates continue their studies and are also entrepreneurial. Product design uses Autodesk Fusion 360 software which supports many CAD features to produce creative and functional 3D designs. The method is carried out in the form of a material presentation seminar on generating design ideas, gathering consumer needs, product design concepts, ergonomics, industrial design, market studies and marketing. Meanwhile, the autodesk fusion 360 material was given in the form of training and was directly guided by the instructors in two days of training. There were 26 students of SMAN 10 Jakarta who participated in this training. The results of the participant's work show that the participants are very enthusiastic, this is also shown in the recapitulation of the questionnaire at the end of the training, where around $92.8 \%$ stated that they were very satisfied with the speaker's explanation and the material provided was felt to be very good with a participant satisfaction level of $94.7 \%$,
\end{abstract}

Keywords: Technopreneurship, Product design, Fusion 360

\begin{abstract}
ABSTRAK
Kebutuhan konsumen era sekarang sangatlah kompleks dan cepat mengalami perubahan. Tentunya ini membutuhkan softskill yang semakin tinggi dalam meresponnya guna mewujudkan desain produk yang sesuai keinginan konsumen. Desain produk yang unik dan kreatif tentunya mempertimbangkan berbagai aspek seperti aspek fungsionalitas, aspek ergonomi, aspek desain industri, aspek mekanikal, aspek manufaktur, termasuk aspek studi pasar dan analisis. Berbagai aspek ini dipandang perlu untuk diperkenalkan dalam bentuk workshop pada Siswa setingkat SMA, seperti pada SMAN 110 Jakarta, yang lulusannya banyak melanjutkan kuliah dan juga berwirausaha. Desain produk menggunakan perangkat lunak Autodesk Fusion 360 yang mendukung banyak fitur CAD untuk menghasilkan desain secara 3D yang kreatif dan fungsional. Metode yang dilakukan dalam bentuk seminar pemaparan materi tentang Pembangkitan ide desain, pengumpulan kebutuhan konsumen, Konsep desain produk, Ergonomi, Desain Industri, Studi pasar dan Marketing. Sedangkan materi autodesk fusion 360 diberikan dalam bentuk pelatihan dan langsung dibimbing oleh para instruktur dalam dua hari pelatihan. Terdapat 26 siswa siswi SMAN 10 Jakarta yang ikut serta dalam pelatihan ini. Hasil karya peserta menunjukkan bahwa peserta sangat antusias, Hal ini juga ditunjukkan pada rekapitulasi kuesioner saat akhir pelatihan, dimana sekitar $92.8 \%$ menyatakan sangat puas dengan penjelasan pembicara dan materi yang diberikan dirasakan sangat baik dengan tingkat kepuasan peserta 94.7\%,
\end{abstract}

Kata kunci: Technopreneurship, Desain produk, Fusion 360

\section{PENDAHULUAN}

Dalam bidang perancangan, pada era sekarang telah berkembang pesat teknologi dalam mewujudkan desain yang sesuai kebutuhan konsumen. Di era sekarang juga peluang-peluang usaha terbuka lebar. Namun untuk menangkap peluang yang ada serta mengetahui kebutuhan 
konsumen tidaklah mudah bisa diprediksi. Dari hasil wawancara pada siswa siswi SMAN 110 Jakarta banyak yang memiliki minat selain melanjutkan kuliah juga berharap bisa memiliki Usaha untuk dikembangkan. Mereka ada yang memiliki ide, Namun merasa tidak memiliki pengetahuan yang cukup apa yang harus dilakukan terhadap idenya tersebut. Persoalan ini menjadi salah satu dasar untuk memberikan pelatihan technopreneurship dan kewirausahaan. Era yang berubah cepat ini, diperlukan soft skill yang juga semakin cepat dengan menggunakan teknologi yang tinggi juga karena pada saat ini perancangan produk juga lebih banyak menggunakan desain yang unik-unik dan kreatif, dengan tidak mengesampingkan aspek-aspek enjiniring, antara lain fungsionalitas, ergonomi, desain industri, aspek mekanikal termasuk aspek manufaktur dan ekonomi.

Salah satu perangkat lunak yang mendukung desain konseptual ini adalah Autodesk Fusion 360. Perangkat lunak ini merupakan perangkat lunak CAD digunakan untuk menghasilkan konsep desain secara 3D. Software ini akan sangat mempermudah proses desain, menekan biaya manufaktur dan mampu menghasilkan visualisasi yang menarik. Oleh karena itu, kegiatan ini dilakukan dengan tujuan dan menawarkan beberapa solusi antara lain, Mengenalkan apa itu technopreneurship, Mengerti dan memahami studi kelayakan bisnis dan rencana pemilihan usaha, Mampu menangkap ide bisnis dan menciptakan peluang bisnis, Mengerti dan memahami faktor apa saja yang dipertimbangkan dalam mendesain sebuah konsep produk serta Mampu mendesain beberapa produk secara konseptual untuk siswa SMA dan sederajat sehingga diharapkan dapat menghasilkan desain produk yang kreatif dan inovatif.

\section{PERMASALAHAN MITRA}

Hasil wawancara yang dilakukan tim pengusul kepada beberapa murid. Permasalahan yang dihadapi terkait dengan technopreneurship adalah sebagai berikut:

1. Kurangnya pengetahuan mengenai cara menangkap peluang ide usaha, survey pasar dan analisisnya serta pengembangan ide produk.

2. Belum adanya pelatihan penggunaan teknologi komputer untuk mendesain ide-ide produk.

Berdasarkan masalah di atas, dapat disimpulkan bahwa para siswa mitra membutuhkan pelatihan dalam menangkap peluang, ide produk, dan pelatihan penggunaan software dalam mendesain ide produk tersebut. Salah satu langkah untuk mengatasi masalah tersebut adalah dilakukan pelatihan technopreneurship.

\section{METODE PELAKSANAAN PKM}

Bentuk Kegiatan pengabdian masyarakat dilaksanakan dalam bentuk ceramah kuliah dan pelatihan. Kegiatan dilaksanakan selama 2 hari dengan beberapa tahap penyampaian materi oleh tim. Mulai dari materi Market riset yaitu bagaimana menangkap peluang pasar sampai ke promosi dan penjualan. kemudian pengenalan konsep produk desain dan pembangkitan ide, lalu materi yang berkaitan dengan ergonomi dan estetika, dan pengenalan mengenai software desain produk. Kemudian tim memberikan pelatihan penggunaan software fusion 360. Penyampaian materi ceramah masing-masing sekitar 45 menit sampai 1 jam. Sedangkan pelatihan dalam beberapa jam selama dua hari. Tahap akhir tim mengevaluasi hasil desain produk di antara peserta pelatihan pembagian kuesioner. Tahapan-tahapan kegiatan ditunjukan pada Gambar 1 . 


\section{Gambar 1}

\section{Tahapan-Tahapan Kegiatan PKM}

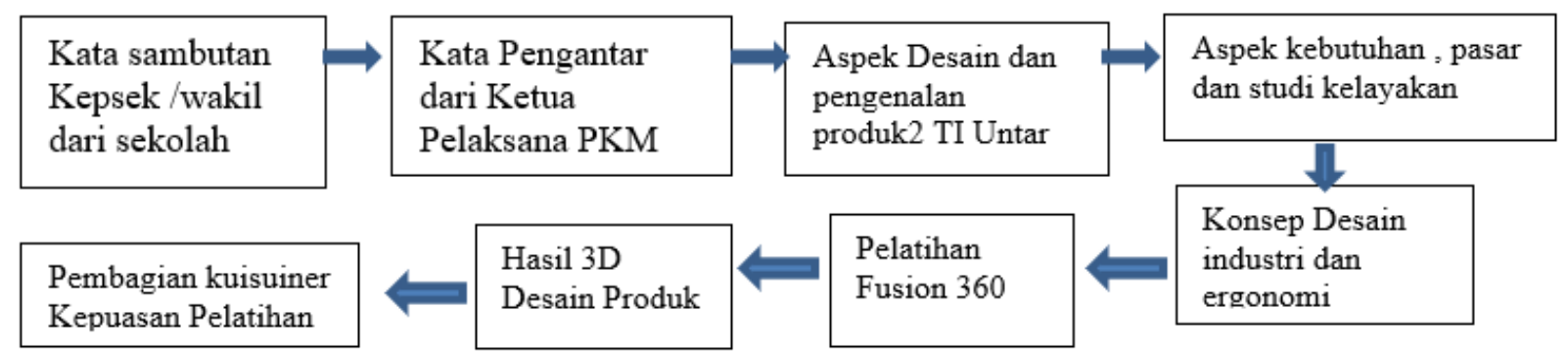

Kegiatan bertujuan meningkatkan kemampuan peserta dalam menangkap peluang ide usaha dan mendesain produk dalam bentuk tiga dimensi yang sesuai kebutuhan konsumen. Program, tujuan dan sasaran kegiatan ini tercantum pada Tabel 1.

\section{Tabel 1}

Program, Tujuan, dan Sasaran Kegiatan

\begin{tabular}{llllll}
\hline No. & Program & \multicolumn{1}{c}{ Tujuan } & Sasaran & \multicolumn{1}{c}{ Materi } \\
\hline 1. & Pemaparan materi & $\begin{array}{l}\text { Peserta mampu menangkap peluang } \\
\text { usaha, memahami aspek-aspek desain } \\
\text { yang harus diperhatikan dari awal } \\
\text { rancangan sampai penjualan produk }\end{array}$ & $\begin{array}{l}\text { Peserta } \\
\text { Siswa }\end{array}$ & $\begin{array}{l}\text { Market research, survey pasar } \\
\text { dan analisis, Konsep Desain } \\
\text { dan pengembangan produk, } \\
\text { Ergonomi dan desain industri, } \\
\text { pengenalan software desain }\end{array}$ \\
\hline $\begin{array}{l}\text { Pelatihan desain } \\
\text { produk dengan } \\
\text { software fusion 360 }\end{array}$ & $\begin{array}{l}\text { Peserta mampu mendesain konsep } \\
\text { produk menggunakan software desain } \\
\text { fusion 360 }\end{array}$ & $\begin{array}{l}\text { Peserta } \\
\text { Siswa }\end{array}$ & $\begin{array}{l}\text { Install fusion 360, pengenalan } \\
\text { fusion 360, penggunaan } \\
\text { fusion 360 dengan contoh- } \\
\text { contoh produk }\end{array}$ \\
\hline
\end{tabular}

\section{Tujuan Pelatihan}

Adapun tujuan dilaksanakan pelatihan adalah sebagai berikut:

1. Mengetahui kemampuan peserta dalam menangkap ide usaha/produk

2. Mengetahui kendala yang dialami peserta dalam mendesain sebuah produk.

3. Meningkatkan kemampuan konsep desain produk peserta dengan software fusion 360

\section{Waktu dan Tempat Kegiatan}

Kegiatan pelatihan/workshop dilaksanakan selama 2 hari, yaitu pada 22-23 Februari 2020. Persiapan dilakukan selama 2 bulan yaitu pada bulan Desember dan Januari. Pelaporan hasil kegiatan pada bulan Juli 2020.

\section{Peserta Kegiatan}

Peserta adalah siswa SMAN 110 Jakarta, Jln Bendungan melayu, Tugu Selatan Rt 9/5, Kec KojaJakarta Utara 14260

\section{Sarana dan Alat yang Digunakan}

Pelatihan diselenggarakan dengan menggunakan sarana ruang kelas di salah satu ruang sekolah di SMAN 110 Jakarta. Ruangan dilengkapi peralatan seperti laptop, proyektor dan kursi meja sebagai pendukung berjalannya proses pelatihan. Selama pelatihan berlangsung disampaikan beberapa materi yang disampaikan melalui proyektor. 


\section{HASIL DAN PEMBAHASAN}

Hasil kegiatan pengabdian ini dibuat dalam laporan kegiatan. Beberapa laporan yang akan diberikan adalah sebagai berikut:

- Gambar 2 merupakan pemaparan tim pengabdian kepada peserta. peserta memperhatikan materi tentang bagaimana menangkap ide usaha, mengumpulkan kebutuhan konsumen, dan aspek-aspek perancangan produk. Dipertemuan ini peserta antusias memberikan pertanyaan-pertanyaan.

- Gambar 3 merupakan pemaparan Tim pengabdian kepada peserta. peserta memperhatikan arahan bagaimana mensurvei pasar, analisisnya dan aspek marketing produk. Dengan ilustrasi dan contoh-contoh pertemuan ini sangat memberi semangat para peserta untuk memperhatikan apa yang disampaikan.

- Gambar 4 pengenalan tim pengabdian kepada peserta Teknik desain produk secara rinci dengan aspek-aspeknya. Dipertemuan ini peserta baru memahami bahwa tahapan dalam desain produk tidak sederhana yang dibayangkan oleh mereka selama ini.

- Gambar 5 Tim memberikan pelatihan mengenai keterkaitan produk dengan pengguna yang menyangkut faktor-faktor keamanan, kenyamanan, dan estetika produk. Disini peserta sangat antusias setelah dijelaskan fungsi dari produk dan aspek yg berkaitan dengan ergonomi.

- Gambar 6 Tim memberikan pelatihan Autodesk fusion 360

- Gambar 7 adalah beberapa hasil desain siswa. Dalam PKM ini tim menggunakan Fusion 360 untuk mendesain gelas. Gelas dipilih karena memiliki Sifat estetika atau keindahan, sifat elastis, dan Sifat ketahanan. Selain dikenal dengan baik oleh peserta, Dari desain gelas tersebut tim bisa memasukan aspek ergonomik, aspek desain industri, serta pemilihan bahan untuk pengembangannya sehingga materi pelatihan yang diberikan, dapat dipahami oleh para peserta.

\section{Gambar 2}

Pemberian Materi Teknik Menangkap Kebutuhan Konsumen dan Pengenalan Konsep

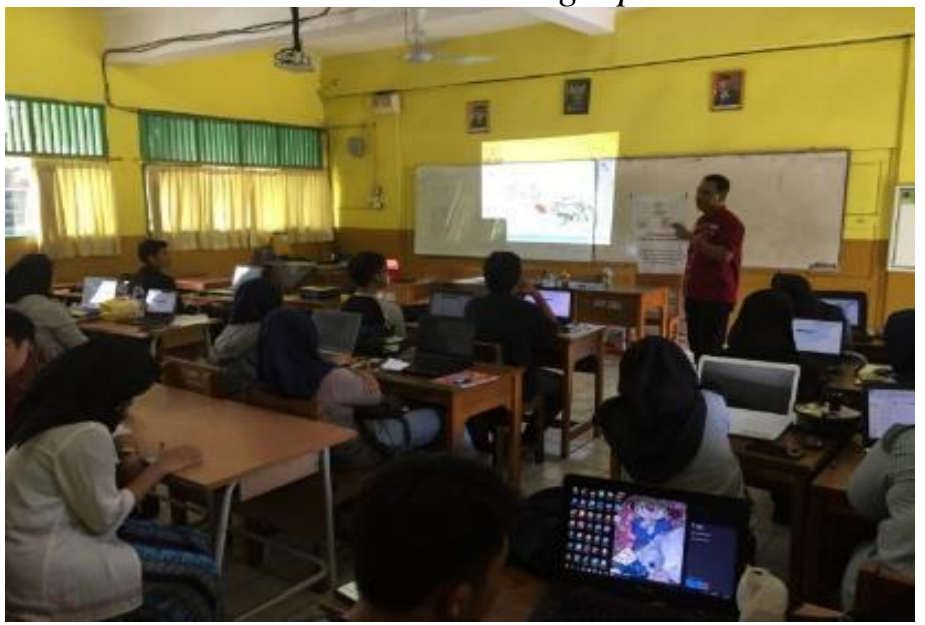




\section{Gambar 3}

Foto Kegiatan Pemberian Materi Marketing, Survey Pasar dan Teknik Analisisnya

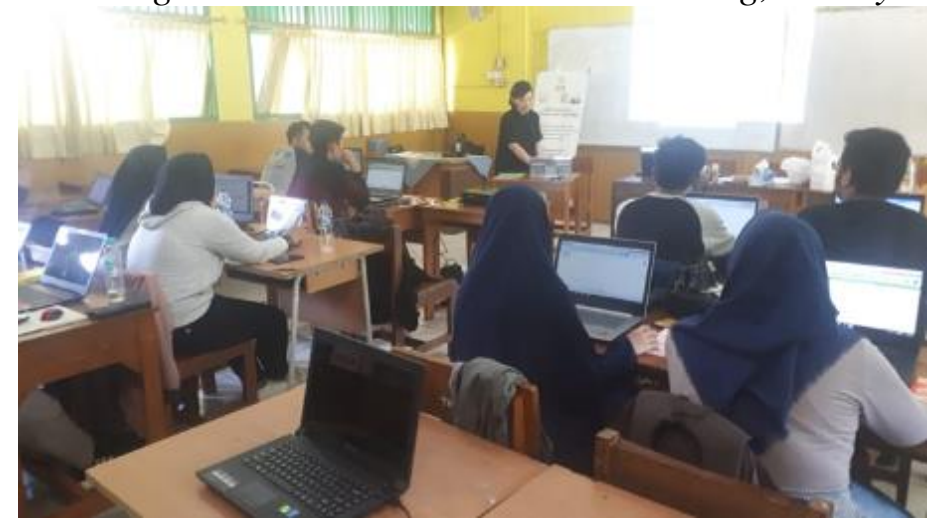

\section{Gambar 4}

Pemaparan Aspek Desain Rinci dan Aspek-Aspeknya.

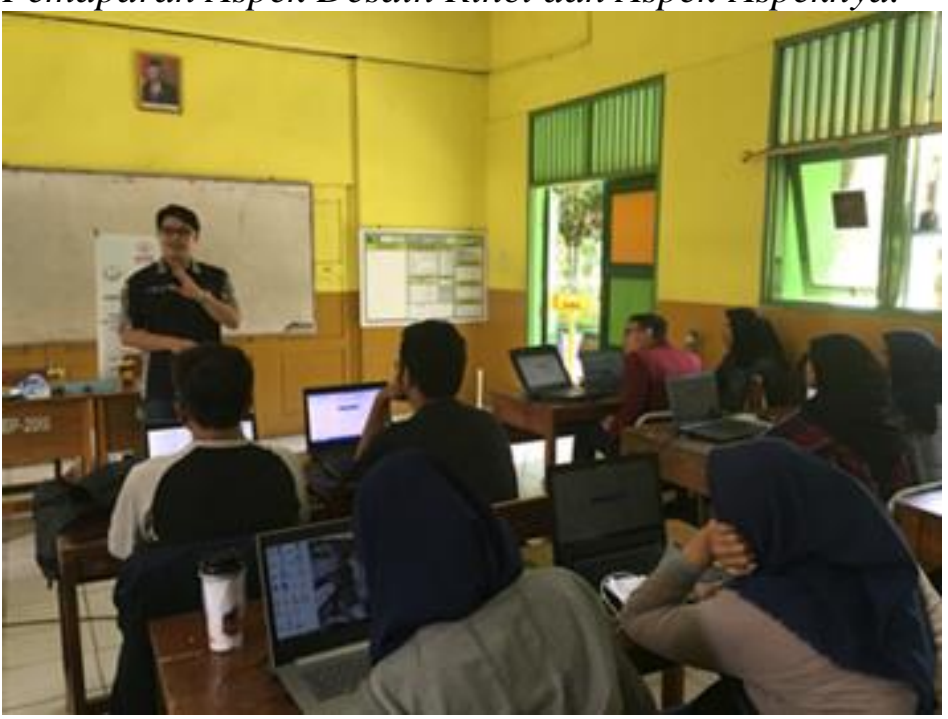

\section{Gambar 5}

Pemaparan Aspek Ergonomi dan Desain Industri Produk

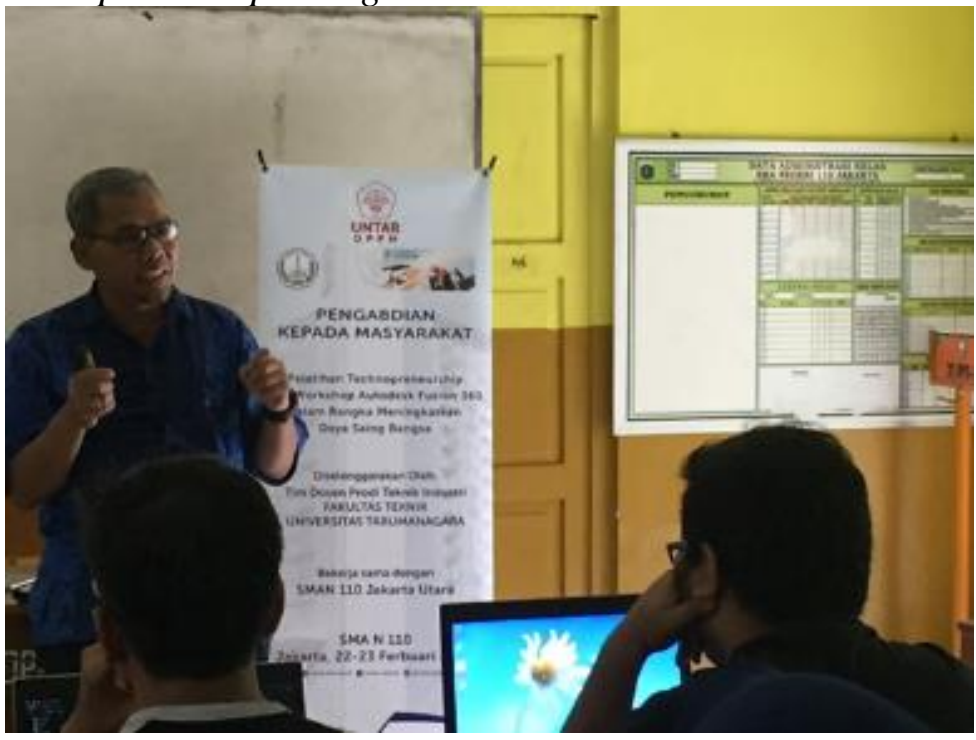




\section{Gambar 6}

Tim Memberikan Pelatihan Autodesk Fusion 360

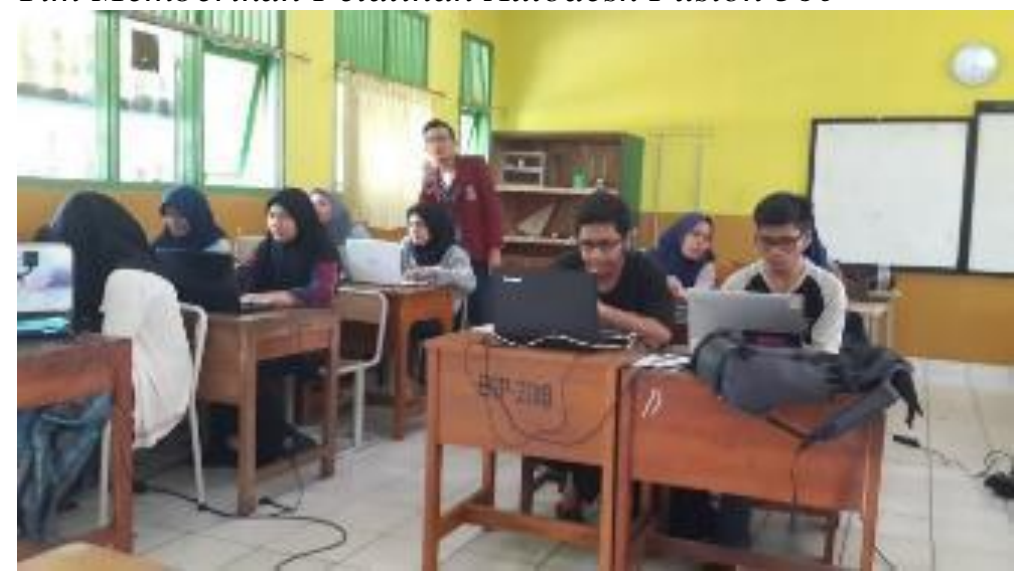

\section{Gambar 7}

Beberapa Hasil Desain Peserta
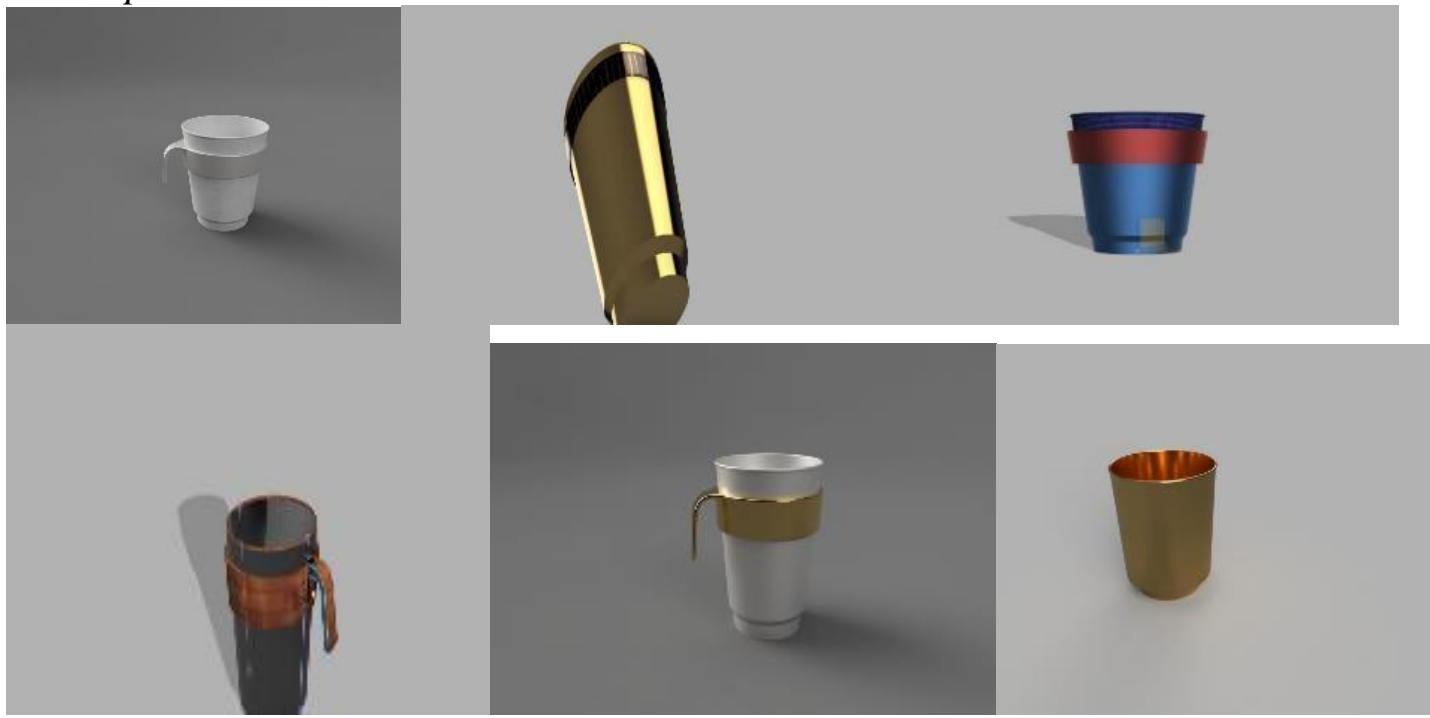

\section{Evaluasi Kegiatan}

Kegiatan evaluasi dilakukan setelah selesai kegiatan. Hasil Evaluasi pelaksanaan pengabdian ini adalah Sulitnya menentukan waktu secara tepat pelaksanaan PKM karena kesibukan sekolah. Kekurangan yang lain dalam pelaksanaan pengabdian PKM ini adalah tim kadang-kadang terkendala dengan alokasi waktu, sehingga pelaksanaan pengabdian kurang maksimal.

Sedangkan hasil kuesioner terhadap peserta dimana peserta diminta untuk mengisi kuesioner yang disebarkan. Hasil tersebut ditunjukkan oleh Tabel 2. 


\section{Tabel 2}

Rekapitulasi kuesioner peserta pelatihan

\begin{tabular}{clcccccc}
\hline \multirow{2}{*}{ No. } & \multirow{2}{*}{ Pertanyaan } & \multicolumn{6}{c|}{ Respon $(\boldsymbol{\%})(\mathbf{1}=$ tidak baik; 6 = sangat baik $)$} \\
\cline { 3 - 8 } & & $\mathbf{1}$ & $\mathbf{2}$ & $\mathbf{3}$ & $\mathbf{4}$ & $\mathbf{5}$ & $\mathbf{6}$ \\
\hline 1. & Relevansi contoh oleh pembicara & 0 & 0 & 0 & 2.2 & 21.6 & 76.2 \\
\hline 2. & Materi & 0 & 0 & 0 & 0 & 42.8 & 57.2 \\
\hline 3. & Penjelasan pembicara & 0 & 0 & 6.2 & 92.8 & & \\
\hline 4. & Manfaat materi & 0 & 0 & 0 & 0 & 5.3 & 94.7 \\
\hline 5. & Ketepatan waktu & 0 & 8.2 & 13 & 12 & 6.8 & 60 \\
\hline 6. & Interaksi & 0 & 0 & 0 & 0 & 8.7 & 91.3 \\
\hline 7. & Persiapan pelatihan & 0 & 0 & 0 & 6.6 & 40.3 & 43.1 \\
\hline
\end{tabular}

Pada tabel 2 ditunjukkan pada rekapitulasi kuesioner pelatihan, dimana hampir seluruh peserta yaitu sekitar $92.8 \%$ menyatakan bahwa penjelasan pemaparan dan pelatihan sangat baik. Sedangkan manfaat serta interaksi tim dengan peserta adalah sangat bermanfaat dan sangat baik .

\section{KESIMPULAN DAN SARAN}

Kegiatan pengabdian kepada masyarakat ini secara umum berjalan dengan lancar. Aspek yang utama, yaitu manfaat bagi peserta pelatihan juga tersalurkan dengan sangat baik dengan tingkat kepuasan peserta $94.7 \%$, serta peserta pelatihan dapat mengaplikasikan pengetahuan yang didapatkan untuk bidang yang ditekuni maupun untuk kegiatan sehari-hari. Hal ini dapat ditunjukkan dengan hasil kuesioner sebesar $92.8 \%$ yang sebagian besar menyatakan bahwa penjelasan pembicara dalam kegiatan ini disampaikan dengan baik serta bermanfaat dan menambah pengetahuan kewirausahaan dan technopreneurship bagi peserta pelatihan.

\section{Ucapan Terima Kasih (Acknowledgement)}

Pada kesempatan ini ucapan terimakasih diberikan sebesar-besarnya kepada Direktorat Penelitian dan Pengabdian Masyarakat Universitas Tarumanagara atas hibah internal yang diberikan pada tim kami, selain itu ucapan terimakasih juga diberikan kepada Kepala sekolah SMAN 110 Jakarta Jakarta atas terselenggaranya kegiatan pengabdian ini.

\section{REFERENSI}

Kotler, P., \& Armstrong, G. (1992). Dasar-dasar pemasaran (5th ed.). Intermedia.

Ulrich, K. T. (2001). Perancangan pengembangan produk (1st ed.). Salemba Teknika.

Tarwaka, Bakri, S. H. A., \& Sudiajeng, L. (2004). ERGONOMI: Untuk kesehatan, keselamatan kerja dan produktivitas. UNIBA.

Kasmir. (2016). Kewirausahaan. RajaGrafindo Persada.

Autodesk Support. (2017, Februari 7). Autodesk knowledge center. Autodesk Inc. https://knowledge.autodesk.com/support/fusion-360

Iskandar, \& Sudarwadi, F. (2020). Gerakan pengentasan pengangguran terdidik melalui strategi perguruan tinggi dalam meningkatkan kewirausahaan bagi mahasiswa di pendidikan tinggi. Jurnal Kewirausahaan dan Bisnis, 25(1), 12-26. https://doi.org/10.20961/jkb.v25i1.31954

Murdiaty, Ferawaty, \& Hita. (2020). Pelatihan desain grafis untuk meningkatkan kreativitas siswa pada SMA Husni Thamrin. Jurnal Pendidikan dan Pengabdian Masyarakat, 3(2), 96-100. https://jurnalfkip.unram.ac.id/index.php/JPPM/article/view/1860/1256 